busca evidenciar a ação da paráfrase discursiva nos movimentos metonímicos e metafóricos que tecem o jogo alusivo, percebendo na obra (auto) biográfica Ler, escrever e fazer conta de cabeça, de Bartolomeu Campos de Queirós (1997), a alusão como estratégia elaboradora de inúmeras costuras de sentido.

\begin{abstract}
The present article analyzes the construction of the allusive game through the description of the category of discursive paraphrase (ORLANDI, 2011) exemplified in the movements of metaphor (condensation) and metonymy (displacement). We start from the premise that considers discursive heterogeneity the mark of a subjectivity always spoken, never center of its saying, thus divided. With the intention of tweaking the construction of meanings in the enunciative process, this work discusses the ways in which the discourse of the one can inhabit the discourse of the other and vice versa. We focus our research on the postulates of Pêcheux (1975), Authier-Revuz $(1982,1990,2007)$ and Torga (2001). Our gesture of analysis seeks to evidence the action of the discursive paraphrase in the metonymic and metaphorical movements that weave the allusive game, perceiving in the (auto) biographical work Ler, escrever e fazer conta de cabeça, by Bartolomeu Campos de Queirós (1997), the allusion as strategy maker of countless seams of meaning.
\end{abstract}

Entradas para indexação

PALAVRAS-CHAVE: Paráfrase discursiva. Alusão. Metáfora. Metonímia. KEYWORDS: Discursive paraphrase. Allusion. Metaphor. Metonymy.

\title{
Texto integral
}

A relação estabelecida entre o ser humano e a linguagem foi sempre ponto alto de discussão entre pensadores de diversas áreas da ciência, em especial no grande campo das ciências humanas. Por muitas vezes defendeu-se a respeito dessa relação uma visão de expressão direta do pensamento, uma representação objetiva de certa ideia, intenção da qual partia o ser da linguagem enquanto origem de todo o dizer. Com o avançar dos estudos e discussões acerca da linguagem, da figura de sujeito e da relação entre ambos, chegamos ao posicionamento de que o(s) efeito(s) de sentido que se constitui dessa relação não se faz no âmbito do dado evidente, uma vez que a linguagem não é translúcida e tampouco o sentido se apresenta como algo a ser acessado de forma direta por meio do ato interpretativo. Em dias contemporâneos, há de se entender que a linguagem é opaca e que os efeitos de sentido são variados e vinculados a contextos históricos-sociaisculturais específicos, em outras palavras, a semântica do discurso precisa ser vista sob a luz da história, das ideologias, das culturas, etc.

Com base nos postulados teóricos de Michel Pêcheux (1975) podemos afirmar a respeito da opacidade da língua ser necessário um gesto de interpretação que objetive a compreensão dos discursos emitidos na/pela linguagem, de forma 
que percebamos o valor histórico a partir da análise da materialidade discursiva. No momento em que estabelecemos tal movimento de análise dos discursos percebemos a existência de diferentes sentidos, divididos socialmente, sentidos que são hierárquicos, não tendo o mesmo valor para todos. Como podemos então explicar o fato de que sujeitos falantes de uma mesma língua podem a partir de uma mesma construção dizer coisas diferentes?

Dessa maneira, com o intuito geral de problematizar a construção de sentidos no processo de enunciação, é mérito desse trabalho de caráter puramente bibliográfico discorrer acerca das formas como o discurso do um pode vir a habitar o discurso do outro e vice e versa. Enfatizamos assim a heterogeneidade do discurso (AUTHIER-REVUZ, 1982; 1990; 2007) marca de uma construção de subjetividade descentrada, nunca senhora do seu próprio dizer, antes, sempre falada.

Nesse ponto deixamos explícita a alusão como possibilidade de trazer à superfície um dizer do outro que fica à margem dos sentidos privilegiados (TORGA, 2001). Evidenciaremos essa possibilidade através dos movimentos de metonímia (deslocamento) e condensação (metáfora) que importam ou deslocam um dizer que está fora, permitindo a emergência do processo alusivo em paralelo com a hipótese conceitual pecheuxtiana da paráfrase discursiva (ORLANDI, 2011). Em nosso gesto de análise fica exemplificada a ação dessas duas categorias no jogo alusivo, em que percebemos em Ler, escrever e fazer conta de cabeça (1997) de Bartolomeu Campos de Queirós, inúmeras costuras de sentido que podem ser desfeitas através da alusão.

\section{Discurso e paráfrase discursiva}

A discussão segue agora em torno do conceito de formação discursiva (FD) frequentemente (re) visitado pelos analistas do discurso e que segundo Pêcheux e Fuchs (1990, p. 166) "aquilo que, numa formação ideológica dada, [...] determina o que se pode e deve ser dito por um sujeito". Conein et al (2016) apontam justamente que esse conceito é para a análise do discurso (AD) o ponto que retoma a relação da interpelação ideológica, momento em que, em um processo de assujeitamento, o indivíduo se constitui sujeito no discurso. É sua inserção em diferentes formações discursivas e seu nível de identificação com as formassujeitos (PÊCHEUX, 1975) ali existentes, que permitirão que os sujeitos concordem, discordem, reiterem, retomem os discursos uns dos outros.

Porém, ainda que pertencentes a uma mesma formação discursiva, a produção de sentido e a compreensão dele não ocorre como algo que se diz e é evidentemente compreendido, como se a relação entre a linguagem e os sentidos construídos a partir dela ocorresse de maneira transparente. Os sujeitos estão inscritos em papéis sociais diversos e de igual forma estão inseridos em formações discursivas diferentes, as quais são naturalmente heterogêneas. No seu todo heterogêneo as formações discursivas tem fronteiras instáveis e tênues, de difícil 
percepção em função de questões de teor ideológico que orientam o que pode e deve ser dito a partir de determinada FD.

Nesse contexto, temos o papel chave do interdiscurso enquanto instância reguladora do deslocamento fronteiriço das formações discursivas. Ao relacionar o interdiscurso com sua visão de FD, Pêcheux (1975, p. 62) afirma:

Toda formação discursiva dissimula, pela transparência de sentido que nela se constitui, sua dependência com relação ao 'todo complexo com dominante' das formações discursivas, intrincado no complexo das formações ideológicas.

O interdiscurso pode, por sua vez, ser visto como um conjunto daquilo que fora anteriormente dito, ou propriamente o já dito de onde se orienta qualquer possibilidade futura de dizer que é marcado pela(s) ideologia(s) circulante em determinada FD sendo assim um complexo influenciado por uma relação de dominância x subordinação. 0 sujeito, então, ao emitir um discurso reitera o que está colocado no interdiscurso considerando sua relação com as FD e suas formassujeito, às quais a produção discursiva vem a ser subordinada. Essa retomada do interdiscurso não se dá de forma clara ao sujeito que, nessa dinâmica, procede por meio da ilusão, ou na visão pecheuxtiana, do esquecimento (PÊCHEUX, 1975) de que seu discurso esteve sempre ali, criando ele a falsa ideia de que é ou tem a origem de seu dizer. Nesse sentido, o interdiscurso apresenta em seu horizonte as possibilidades daquilo que pode ser emitido a partir de cada formação discursiva, sendo assim, peça fundamental para as distinções e especificidades no âmbito de cada formação e das relações de câmbio de sentidos que ocorrem entre elas.

Como sugere Pêcheux, cada formação discursiva tem uma referência construída de um dado objeto, não havendo uma universalidade histórica na visão do objeto em questão no que concerne a diferentes formações discursivas. Essas diferentes referências de sentido em cada FD são marcadas diretamente por posicionamentos ideológicos em que cada sujeito, uma vez já ideologicamente interpelado, sustenta determinados papeis constatáveis a partir da análise de discursos e da formação discursiva em que eles se inscrevem. Fica nítida a interdependência entre a formação ideológica e a formação discursiva já assinaladas por Pêcheux e Fuchs (1990) e aqui retomadas por Brandão (1998, p. 38) quando reitera que "são as formações discursivas que, em uma formação ideológica específica e levando em conta uma relação de classe, determinam o que pode e deve ser dito a partir de uma posição dada em uma conjuntura dada".

Ainda que as formações discursivas sejam ideologicamente marcadas e distintas, a inserção do sujeito em diferentes FD e o seu consequente transitar por elas fazem com que os valores e sentidos que se vinculam a determinadas formações possam transitar junto com os sujeitos. Cria-se nesse caminho, ocasião para o deslizamento de sentidos, uma amplitude de possibilidades para o dizer que só coaduna com a hipótese da não cristalinidade do sentido. Assim, por meio de associações ou metáforas: 
[...] elementos da sequência textual funcionando em uma formação discursiva dada, podem ser importados (metaforizados) de uma sequência pertencente a uma outra formação discursiva [...] as referências discursivas podem se construir e se deslocar historicamente. (ORLANDI, 2011, p. 158).

$\mathrm{Na}$ prerrogativa apresentada, o interdiscurso torna-se "princípio de funcionamento" (ORLANDI, 2011, p. 158) da discursividade num processo descrito como paráfrase discursiva. 0 papel da metáfora nesse processo é de atuar como uma perturbação nos efeitos de sentido operando, assim, na direção da polissemia. Em contrapartida, tem-se na figura da metonímia um movimento que busca organizar ou ordenar o movimento metafórico, trazendo na forma de deslocamentos ou combinações uma sensação de ilusória objetividade ao efeito de sentido produzido nesse processo.

Vemos, então, nesse ponto a possibilidade de polissemia num diálogo direto com um dos esquecimentos mencionados por Pêcheux (1975) descrito anteriormente nesse texto. Os sentidos metaforizados e metonimizados que acabam atualizando o interdiscurso no tocante a uma determinada FD, são consequências de uma plena identificação do sujeito à forma-sujeito. A inserção e circulação desse sujeito em distintas formações discursivas faz com que ele tenha acesso a diferentes versões de um "mesmo" dizer, daí, no momento em que o discurso é emitido existe a possibilidade de importar o sentido por um processo de condensação (metáfora) ou deslocamento (metonímia), movimentos que marcam a alusão a outro dizer oriundo de uma formação distinta e caracterizam a paráfrase discursiva.

A depreender do quadro construído até esse ponto, a relação inderdiscursiva dos já ditos e o que pode ser dito é regulada pelo interdiscurso partindo das relações que este estabelece com as formações discursivas ao longo da história. Analisar o discurso, nesse âmbito, requer a compreensão de que os sentidos são construídos historicamente através da linguagem e que o que é dito se apresenta através de uma possibilidade de sentidos, dispersa em formações discursivas diferentes que estão em constante interação em função dos diferentes papéis que o ser da linguagem pode ocupar.

\section{O outro no discurso}

Discutimos até aqui brevemente acerca das categorias de sujeito, discurso e da relação de ambos com a linguagem, a fim de deixar espaço aberto para pensar a relação da paráfrase discursiva no processo de funcionamento do discurso. Abordando esse movimento de construção discursiva salientado na ação das categorias metáfora e metonímia, nos debruçamos acerca das possibilidades de sentido que se dão na/pela inserção do discurso do "outro" no discurso de "um". 
Jacqueline Authier-Revuz é quem endossa essa visão alegando, entre outras coisas, ser impossível conceber a existência de uma palavra plenamente unívoca, desatrelada do discurso de outrem. Authier-Revuz propõe atestar a natureza cindida do sujeito, constituído pelo dizer alheio. Como ela propõe:

As palavras são sempre e inevitavelmente as palavras dos outros. [...] Nenhuma palavra é "neutra", mas inevitavelmente "carregada", "ocupada", "habitada", "atravessada" pelos discursos nos quais viveu sua existência socialmente sustentada. [...] os outros discursos não como ambiente que permite extrair halos conotativos a partir de um só sentido, mas como um 'centro' exterior constitutivo, aquele do já dito, com o que se tece, inevitavelmente a trama mesma do discurso. (AUTHIER-REVUZ, 1990, p.26, grifos da autora).

A esses pontos levantados, em especial com relação ao papel do outro no que condiz o já dito, Authier-Revuz contrapõe com a ideia do funcionamento do interdiscurso na teoria pecheuxtiana, sinalizando que o sujeito é essa figura descentrada, distante de seu próprio dizer e atravessada sempre pelo discurso de outrem. Assim, esse discurso do sujeito e por consequência o próprio sujeito são sempre falados pelo outro, outrossim, o que se torna evidente é o caráter heterogêneo do discurso, plenamente habitado por uma disputa de sentidos em relação hierarquizada. A heterogeneidade discursiva é apresentada por AuthierRevuz (1990) em duas categorias: heterogeneidade mostrada e heterogeneidade constitutiva.

A heterogeneidade mostrada, como o termo em si sugere, torna a heterogeneidade do discurso mais evidente, por meio de maior imediatismo, manifestações explícitas da ação do discurso do outro no discurso do um. A forma mostrada se orienta a partir do uso de marcas linguísticas que podem, de forma explícita, sinalizar esse discurso alheio no fio do discurso, como: as glosas, as aspas, o discurso direto, o discurso indireto, a paráfrase/paródia, etc. Segundo AuthierRevuz (1990), mesmo que essas marcas especifiquem que há uma voz de alteridade inserida naquele discurso, é necessário que todo o processo de interpretação passe "por uma especificação da alteridade a que remetem, em função de seu ambiente discursivo" (AUTHIER-REVUZ, 1990, p. 30). A partir das possibilidades de evidências podemos remontar o traçado desse discurso alheio percebendo que se trata de outras vertentes, vozes distintas e até opostas, outras modalidades de concepção de um sentido que são impressas no intradiscurso (PÊCHEUX, 1975). Como aponta Authier-Revuz, de maneira a resumir:

As distinções operadas pelas formas marcadas de heterogeneidade mostrada relevam de uma relação de um ao outro, inscrita no comparável, no comensurável, na pluralidade. (AUTHIER-REVUZ, 1990, p. 31, grifos da autora). 
A heterogeneidade constitutiva sugere uma modalidade de heterogêneo em que o discurso do outro é perceptível por um patamar distinto. Não mais tratado no nível do explícito, aborda-se aqui um nível de heterogêneo que constitui o discurso sob outro arranjo, residindo de forma implícita na materialidade discursiva como uma característica inerente e própria do discurso, não exterior como soa a heterogeneidade marcada. Como já discutido anteriormente, o trânsito do ser da linguagem ocupante de variados papéis de sujeito e disperso em diversas formações discursivas, permite um cambio entre as possibilidades de sentido que determinada expressão vem a ter com base na sua relação com o interdiscurso. Por mais que esses argumentos em algum ponto sugiram a autonomia do sujeito em relação ao seu próprio discurso, resgatamos aqui a plena identificação à forma sujeito como fator que viabiliza esse movimento do sujeito, esquecido de que não é senhor do seu dizer.

Nesse sentido cabe ainda acrescentar que as formas dessa heterogeneidade constitutiva emergem ao produzir "um buraco no discurso, elas dão a imagem de um espaço, de uma sutura sublinhada pela costura que o anula" (AUTHIER-REVUZ, 1990, p. 34). Essa costura de sentido que tenta preencher esse buraco no discurso causado pelo discurso de outrem, em um ponto cumpre seu papel de esconder um sentido outro ao qual se sobrepõe uma primeira camada de sentido. No entanto, ainda que menos evidente, ou melhor, ocultado, pode-se chegar a esse sentido quando há acesso à formação discursiva em que ele circula, desfazendo-se assim o remendo de uma "costura aparente" que oculta esse sentido outro. 0 discurso indireto livre, a ironia, jogos de palavras são possibilidades que referenciam a heterogeneidade constitutiva no discurso, segundo Authier-Revuz (1990). A pesquisadora sinaliza ainda a metáfora, e, respaldados em Torga (2001), sinalizamos ainda a metonímia como pontos desse viés sobre o heterogêneo que propõe "a diluição, [...] a dissolução do outro no um, onde este, precisamente aqui, pode ser enfaticamente confirmado mas também onde pode se perder" (AUTHIERREVUZ, 1990, p. 34).

Com a heterogeneidade constitutiva em perspectiva podemos traçar paralelos em relação a categoria de paráfrase discursiva anteriormente discutida. 0 dizer alheio é incorporado ao discurso do um, deixando em algum ponto brechas para que efeitos de sentido menos privilegiados possam ser acessados durante a enunciação, considerando-se ainda que o processo de produção de sentido se dá socialmente. Em meio a esses contrapontos, a alusão figura como estratégia elaboradora de sentidos se configura como possibilidade de intersecção para esses conceitos, sendo uma ponte de acesso aos dizeres que estão à deriva.

\section{Alusão: rumo à margem}

Como percebemos na distinção entre as categorias de heterogeneidade mostrada e constitutiva nos postulados de Authier-Revuz retomados até esse ponto, o outro no discurso do um nem sempre é tão marcado. Para resgatar esse discurso alheio que pode se esconder no emaranhado do fio discursivo é necessário um gesto de leitura, de interpretação que reconstitua esse traçado. 
Nesse sentido Authier-Revuz (2007, p. 11) entende a alusão como um processo discursivo que "põe em cena a enunciação e suas heterogeneidades, a discursividade, o sentido". Suscitamos aqui, dessa forma, a proposta da alusão nos postulados de Torga (2001) que enquanto movimento orientado por processos de metáfora e metonímia "torna o indizível, dizível" (TORGA, 2001, p. 47). Nos é proposta pela pesquisadora a hipótese de que:

Todo movimento alusivo é o da busca dialética - que difere do movimento vertical (1), do horizontal (2) e que se constitui na relação contraditória dos dois e que resulta, no movimento espiral (3) do todo: a busca do sentido dialeticamente constituído em movimento espiral parte/todo. A parte é o 'um', a repetição e o todo constitui o outro, a transformação. (TORGA, 2001, p. 42).

No contexto acima discutido, nos é possível pensar que essas relações entre os movimentos de orientação (1) vertical e (2) horizontal que propõe a pesquisadora colocam o jogo alusivo numa perspectiva de interação entre interdiscurso e intradiscurso. 0 interdiscurso é nessa visão a orientação vertical que remonta ao eixo paradigmático em Saussure (1974), pressupondo as possibilidades lexicais que caberiam naquele ponto da enunciação. Já o intradiscurso se coloca no sentido do eixo sintagmático, na horizontal, marcando o fio do discurso, ou seja, o que é realmente dito. 0 que marca o processo de alusão nessa perspectiva é uma movimentação não de perpendicularidade entre ambos, mas, em profusão proveniente de uma (3) espiral, vemos o jogo alusivo como uma espécie de leitura assimétrica que não prevê a interpretação através de um gesto objetivo emanante de uma relação direta entre interdiscurso e intradiscurso. A busca dos possíveis sentidos parte da contradição entre o que ao mesmo tempo é apenas o um, o evidente, repetido e que, com a entrada do outro, passa-se a pensar uma transformação, ou seja, uma espécie de perturbação que ocasiona num então todo.

Cabe a nós aqui mencionar, no viés de Authier-Revuz (2007), os dois diferentes lugares e as respectivas relações que ocorrem em cada um, sem as quais não são reunidas condições para que ocorra a alusão: "a linha do dizer e o espaço do já-dito - através de dois tipos de relação - diferença no intradiscurso e semelhança no interdiscurso, estranhamento no dizer aqui e familiaridade no ali do exterior" (AUTHIER-REVUZ, 2007, p. 21). Ou seja, é necessário que inicialmente haja um estranhamento perceptível na ordem do todo da enunciação que permita ao sujeito compreender que os sentidos aludidos residem num discurso alheio, possibilidades de sentido reiteradas de uma outra FD por paráfrase discursiva, por exemplo. Entretanto, sem a sensação de familiaridade descrita acima, oriunda justamente do contado daquele sujeito com uma FD onde circulam aquelas possibilidades de dizer, a alusão será "tranquilamente ignorada sob a igualdade aparente de uma linearidade sem ruptura" (AUTHIER-REVUZ, 2007, p. 24). Retomamos aqui o que fora suscitado por Freud (1996) em seus experimentos com os chistes: o sentido tem seu teor social e, portanto, é necessário que os sujeitos 
circulem em FD comuns para que tenham acesso a possibilidades de sentidos em alusão.

Tangenciando ainda o funcionamento da alusão em contraposição com os aportes teóricos até aqui debatidos, é oportuno mencionar a ação da metáfora e da metonímia sob a forma de gestos nos quais pode estar organizado o jogo alusivo. Essas duas categorias rearranjam numa interface linguístico-semântica a alusão, considerando a em relação à heterogeneidade constitutiva. Esta última posta como traço inerente ao jogo alusivo, no ponto em que metáfora e metonímia (deslocamento e condensação) fazem "falar no vertiginoso apagamento do enunciador atravessado pelo 'isso fala' do interdiscurso ou do significante" (AUTHIER-REVUZ, 1982, p. 34).

\section{0 jogo alusivo em Ler, escrever e fazer conta de cabeça}

Com base nas últimas considerações, descrevemos a seguir o funcionamento da alusão através dos movimentos de metáfora e metonímia enquanto portas de entrada para o discurso do outro no discurso do um. Como corpus do nosso gesto de análise selecionamos a obra literária Ler, escrever e fazer conta de cabeça, do escritor mineiro Bartolomeu Campos de Queirós.

A obra em questão integra o projeto autobiográfico de Queirós, composto por diferentes momentos da infância do autor, obras que são desenvolvidas com tonalidades e temas que se entrelaçam e se relacionam no campo do relato de memórias. As conexões entre as obras que integram esse projeto autobiográfico ficam evidentes no seu próprio desenrolar como, por exemplo, a referência às paredes da casa de seu avô paterno cobertas de escritos, cenário onde se desenrolam os relatos de Por Parte de Pai (1994): "Eu lembrava da casa de meu avô e suas paredes cobertas de recados, mas minha cabeça não sabia combinar (QUEIRÓS, 1997, p. 38). Iniciado com Indez (1994) e concluído com Vermelho amargo (2011), pouco tempo antes da morte do escritor, as obras (auto)biográficas de Queirós trazem a realização, numa escrita de si, das memórias do menino-narrador que agora adulto reconstrói suas experiências de infância.

Nesse entremeio, Ler, escrever e fazer conta de cabeça se configura como uma obra autobiográfica, que nos contornos do que propõe Arfuch (2010) integraria o que ela chama de espaço biográfico, um conceito que abrange obras de matizes (auto) biográficos funcionando mais especificamente como:

Confluência de várias formas, gêneros e horizontes de expectativa [...] permite a consideração das respectivas especificidades sem perder de vista a sua dimensão relacional, sua interatividade temática e pragmática, seus usos em vários campos da comunicação e ação. (ARFUCH, 2010, p. 49, tradução nossa). 
Nesse viés, a obra se divide em uma série de diversas passagens memorialísticas contadas numa escrita intimista chamada prosa poética que busca "fixar um olhar lírico sobre a realidade" (PAIXÃO, 2013, p. 152) com base na ressignificação daquilo que foi uma vez vivido.

Se considerarmos a autobiografia como resultante da relação discursiva construída nas relações espaço-temporais entre autor-leitor-obra veremos ao longo desse caminho a memória sendo usada pelo autor como instrumento sob o qual é possível a elaboração de uma constante reconstrução das vivências que marcaram uma vida e, portanto, circulam no espaço mnemônico. Denotamos, portanto, o olhar ressemantizador, que vê no uma vez vivido porta aberta para uma percepção não excludente, mas em todo modo valorativa, como endossado por Torga (2005, p. 79):

A identificação e a contemplação se dão via memória, que, enquanto refacção, re-vivência, deve ser entendida não como preenchimento de lacunas, mas como a própria lacuna onde há a subversão da ordem, o amarrotamento, a rasura do que foi.

Orientada por um padrão de tempo psicológico e com foco narrativo em primeira pessoa, a narração das experiências de vida do jovem Bartolomeu traz à tona as cores e os sabores de sua infância permeada enfaticamente por ausências, lacunas, vazios os quais em Ler, escrever e fazer conta de cabeça são preenchidos pelas experiências com o mundo das palavras. Dispomos, então, de alguns trechos da obra em que percebemos certas modalidades de ação do discurso alheio que representariam, dessa forma, partes que compõem o todo de uma grande trama discursiva envolvendo a autobiografia em questão. São descritas, para este fim, falas sociais que constantemente atravessam o discurso do um, nesse caso ilustrado pelo menino-narrador-adulto.

Em primeiro plano, é impossível não se deter acerca do título do próprio livro, Ler, escrever e fazer conta de cabeça configura-se por deslocamentos que objetivam e aludem a um relevante desenlace no âmbito dessa história que é apontado pelo menino-narrador já na primeira passagem: sua relação com a escola e o que aquilo representaria dentro de seu mundo:

(1) Parecia muito pequeno o ideal de meu pai, naquele tempo, lá. A escola, onde me matriculou também na caixa escolar - para ter direito a uniforme e merenda-, devia me ensinar a ler, escrever e a fazer conta de cabeça. 0 resto, dizia ele, é só ter gratidão, e isso se aprende copiando exemplos. (QUEIRÓS, 1997, p. 7).

O ideal do pai descrito como pequeno e os demais discursos imbricados na sequência discursiva em questão aludem a um ponto em comum por uma série de deslocamentos que provocam a sensação de que o sentido está sempre sendo adiado. A escola é o ponto de intersecção ao qual está sendo deslocado o sentido 
em um dado ponto. 0 ensino de ler, escrever e fazer conta de cabeça seria para o pai do menino uma função da escola que marcaria a vida do garoto. 0 que para o narrador é agora visto como algo pequeno simbolizava para o pai um grande rito social que se encerra na relação metonímica entre esses três elementos e o sentido atrelado ao termo escola. Ainda sob a ideia do adjetivo pequeno, coloca o narrador a expressão simplista resto enfatizando por oposição o grande valor que a escola teria na vida do filho. Ou seja, se tudo que ele aprenderia fora da escola copiando exemplos cabe no reducionismo resto, ler, escrever e fazer conta de cabeça é uma projeção deveras importante e estimada para a formação cidadã do narradorpersonagem, na visão endossada por seu pai.

No fragmento (1) vemos a presença da heterogeneidade mostrada no ponto em que o narrador de maneira indireta sinaliza a visão do pai e as expectativas que ele tinha sobre o futuro e educação do filho. 0 valor que a escola possui, nesse ponto, é introduzido pela visão lançada pelo pai do narrador, sendo essa instituição de ensino resposta para tudo que o então menino necessitava para ser bem sucedido.

Para o menino-narrador, as visões acerca da escola são percebidas de uma forma um tanto mais ampla evidenciando uma contraposição com relação à visão que tinha o pai. Para o menino o ato de ler, escrever e fazer conta de cabeça que para o pai encerra o que seria a função da escola alude a uma maior possibilidade de experiências, horizontes e oportunidades:

(2) [...] havia a vontade de desamarrar os nós, entrar em acordo com o desconhecido, abrir o caderno limpo e batizar as folhas com a sabedoria do mistério, abrir portas para receber novas lições, destramelar as janelas e espiar mais longe. Tudo isso me encantava. (QUEIRÓS, 1997, p. 8).

Destacamos nesse trecho um tom de estranhamento em relação ao valor atribuído às possibilidades de experiência escolar do menino-narrador-adulto, em que não parece condizer com o olhar da criança, ainda que seja ela a personagem central da narrativa. De fato, por se tratar de um narrador adulto relatando e ressignificando suas memórias de infância, os efeitos de sentido no âmbito do fragmento (2) se filiam a possíveis FD em que circula um sujeito constituído por discursos que concebem valores um tanto marcados para a educação. Podemos inferir pelos tipos de comparações feitas por meio das relações metonímicas em "entrar em acordo com o desconhecido, abrir o caderno limpo e batizar as folhas com a sabedoria do mistério, abrir portas para receber novas lições, destramelar as janelas e espiar mais longe" que se trata de um sujeito que parece acreditar numa visão de educação enquanto possibilidade de empoderamento, criticidade e libertação, que se posiciona em oposição a uma concepção de mera reprodução de conhecimentos. Se tratando de uma autobiografia e pressupondo uma relativa "unidade" entre as categorias de autor, narrador e personagem, podemos ir além e analisar dados biográficos acerca do sujeito autor, confirmando a hipótese de que os sentidos atribuídos à escola no último fragmento partem de um sujeito que tem 
seu discurso atravessado por um ideário de educação libertária. 0 discurso alheio que irrompe aqui é potencialmente condizente com o professor, o teórico, o pesquisador, etc., que não fazem parte da cena enunciativa em que habitam as personagens da vivência relatada, mas que atravessam o autor, parte dessa identidade fragmentária que se acredita ser o mesmo sujeito que uma vez vivenciou tais acontecimentos.

Em outros pontos, as memórias do menino-narrador-adulto ao longo da obra divagam principalmente acerca de sua relação com a escola e com tudo que ela poderia lhe ensinar. Dispomos, então, de vários outros momentos em que claramente um falar social que envolve a escola e demais elementos que a esse campo se relaciona, como a professora, especialmente, irrompem no discurso do menino-narrador de forma recorrente:

(3) A professora gostava de vestido branco [...]. Ninguém tinha maior paciência, melhor sabedoria... (QUEIRÓS, 1997, p. 44).

(4) A professora decidia sobre os ensinamentos importantes, consultando seu caderno de plano de aula com capa de papel de presente. (QUEIRÓS, 1997, p. 49).

(5) Também a professora tinha voz doce e lisa que passava a morar dentro de nós. (QUEIRÓS, 1997, p. 52).

(6) Assim, sem alarde, a escola ia nos ensinando a liberdade de ser muitas coisas, apagando o medo de não vencer o depois. (QUEIRÓS, 1997, p. 74).

Nos trechos 3, 4 e 5, fica perceptível a voz da professora em alusão no discurso do menino narrador. Pelo o uso de condensações, o sentido que se constrói em torno do termo professora, está sempre para a figura pura, delicada (gostava de vestido branco, voz doce e lisa) e respeitável (maior paciência, melhor sabedoria). Sustentando essas características levantadas nos discursos sobre a professora, a metáfora perceptível na relação dos ensinamentos importantes com a imagem do caderno de plano de aula com capa de papel de presente dá profusão à ideia de que aprender o que a professora tinha para ensinar a cada aula seria equiparável à alegria de receber um presente, que traz consigo uma sensação de expectativa, ansiedade ou até mesmo surpresa pensando nas possibilidades de um presente como algo muitas vezes inesperado. De toda forma, a professora e aquilo que ela tinha a ensinar eram vistos pelos alunos com satisfação e encanto, através do olhar do menino-narrador.

Falares sociais que marcam discursos relacionados à/sobre a família do narrador são corriqueiramente vistos ao longo das passagens do livro. A mãe é muitas vezes retratada como a figura de cuidado e de quem se quer atenção, já o 
pai é representado com a visão daquela pessoa sem muita escolaridade, simples e objetiva nas ideias, que trabalha, se esforça demasiadamente para o sustento da família e está frequentemente cansado, desanimado, fadado a trabalhar para prover o sustento da família. Na citação a seguir descreve-se um momento em que irrompe a visão de uma figura do discurso cristão, o anjo, em vínculo ao pai e ao seu discurso que atravessa o narrador:

(7) Difícil não conferir razão a meu pai em seus momentos de anjo. Ele pendia a cabeça para a esquerda, como se escutando o coração e falava sem labirintos. Dizia frases claras, acordando sorrisos e caminhos. Parecia querer argumentar sem ele mesmo ter certeza, tornando assim as palavras cuidadosas. (QUEIRÓS, 1997, p. 7).

0 pai está aqui associado à figura do anjo, oriunda do discurso cristão que, dentre outras possibilidades, pode ao mesmo tempo: i) simbolizar proteção, enquanto um emissário do poder de Deus para ajudar os homens, ii) inocência, pureza, marca do fator sagrado de que a figura angelical está imbuída e iii) imagens e esculturas comumente juntas aos santos, característicos de uma FD cristãcatólica, evidenciado no movimento de cabeça similar nessas peças que pode significar complacência. A alusão que enxergamos nesse ponto é construída por efeito metafórico que importa esse sentido de um lugar exterior à cena enunciativa e por condensação dá margem a outro(s) dizer(es).

Além dessas marcas de heterogeneidade, percebemos a ocorrência de outros momentos em que o fio do discurso do menino-narrador é atravessado por formas discursivas oriundas de um discurso cristão. No trecho (8) de forma bem direta há a menção do vai com Deus enquanto reiteração da proteção divina e da figura do Anjo-da-Guarda proveniente do imaginário cristão, também uma forma de garantia da ação protetora sagrada sobre a vida do menino. A condensação dessas figuras aqui em vínculo com a relação familiar marca a ação protetora, de cuidado que a família demonstrava em relação à criança. Além disso, nesse trecho presenciamos uma série de deslocamentos que também aludem à relação da família com o narrador, demonstrando o tipo de amor construído nessa relação familiar, um amor que se vai desde o sabor de uma bala, ao cuidado no olhar, no momento de catar piolhos e na "contação de histórias":

(8) Tudo eu fazia, mesmo com sofrimento, para ser amado. E a obediência era uma condição. Mas o amor compensava tudo. Ele chegava num pedaço de doce a mais, num olhar mais prolongado acariciando o coração, num 'vai com Deus' na saída para a escola, num quadro de Anjo-da-Guarda na cabeceira a cama, num pente fino pelos cabelos procurando piolhos, numa história de outro mundo contada na beira do fogão. (QUEIRÓS, 1997, p. 11). 
(9) Ser obediente demandava muito sacrifício. Não por natureza, mas por conveniência eu crescia obedecendo. Cumpria, de maneira exemplar, todos os deveres de filho, de aluno, de colega, sem acrescentar resmungos. Comia com a boca fechada até quebra-queixo ou puxa-puxa; dormia cedo mesmo sem sono, não escutava conversa de adultos, escrevia com a letra bonita; carregava simpatia no pescoço sem reclamar, não perguntava como carregar água na peneira, não jogava conversa fora. (QUEIRÓS, 1997, p. 10).

(10) A pobreza pesava bastante sobre os ombros de meu pai. Trabalhava dia e noite, estrada afora, vencendo lama e poeira, regressando cansado, lastimoso, e ainda carregando água na peneira. (QUEIRÓS, 1997, p. 11).

Nos trechos 9 e 10, percebemos mais um caso de uma construção metafórica, em torno da expressão carregar água na peneira. Em uma versão seria uma tarefa difícil de ser realizada em vista da relação física nas condições materiais dos objetos em questão (água x peneira). É nessa relação que podemos por em ação o jogo da alusão que importa de um discurso alheio a ideia de que justamente por ser algo difícil era algo a ser evitado, pensando no fato de que criança não deve fazer perguntas difíceis. A mesma expressão é colocada em outro ponto da narrativa, porém, agora aludindo à outra possibilidade, carregando água na peneira no trecho (10), retoma o sentido condensado nos sonhos do pai, como se o que ele sonhava fosse algo impossível de ser alcançado, porém, ao mesmo tempo não deixava de fazê-lo, assim persistia em sonhar seus sonhos distantes.

\section{Considerações finais}

No quadro apresentado até aqui destacamos as possibilidades de intersecção entre as contribuições teóricas que alicerçam esse trabalho. Inicialmente, a categoria de paráfrase discursiva descreve a forma como ocorrem os intercâmbios de sentido entre FD distintas. Esse movimento é possibilitado por meio da participação do indivíduo interpelado pela ideologia, sob a égide do interdiscurso e seu saber dominante, em diferentes formações discursivas.

Esses intercâmbios lidam com a inserção do dizer alheio no discurso desse sujeito que não é autor de seu próprio discurso (por mais que tenha essa ilusão), porém, é já sempre falado. 0 dizer do outro no discurso do um emerge por meio de algumas formas de heterogeneidade que são presentes no fio do discurso de maneira evidente, seja na heterogeneidade mostrada ou de forma mais implícita, na heterogeneidade constitutiva.

Como vimos aqui através das teorias em torno do processo de alusão, a inserção desse dizer alheio dialoga com os movimentos de deslocamento e condensação descritos como propostas de um dizer que se situa à margem. A 
alusão é, por esse olhar, uma via de acesso para os sujeitos a fim de alcançar possíveis sentidos que subjazem um dizer saturado; o outro pode ser encontrado no emaranhado da enunciação que envolve o mesmo.

Nesse sentido, o gesto de análise aqui demonstrado destacou a forma com que a alusão atua por meio de uma relação não tão simétrica entre interdiscurso e intradiscurso. A metáfora e a metonímia são, além de movimentos que permitem a paráfrase discursiva, estratégias que colocam em cena o jogo alusivo, deslocando ou condensando o sentido, indicando a uma amplitude de sentidos à margem do dizer estabilizado.

\section{Referências}

ARFUCH, Leonor. El espacio biográfico: dilemas de la subjetividad contemporánea. Buenos Aires: Fondo de Cultura Económica, 2010.

AUTHIER-REVUZ Jacqueline. Hétérogénéité montrée et hétérogénéité consti- tutive, éléments pour une approche de l'autre dans le discours. DRLAV, Paris, n. 26, p. 91-151, 1982.

AUTHIER-REVUZ, Jacqueline. Heterogeneidade(s) enunciativa(s). Cadernos de estudos linguísticos, Campinas, n. 19, p. 25-42, jul./dez. 1990.

AUTHIER-REVUZ, Jacqueline. Nos riscos da alusão. Tradução de Ana Vaz e Doris Arruda Carneiro da Cunha. Revista Investigações, Recife, v. 20, n. 2, jul. 2007.

BRANDÃO, Helena H. N. Subjetividade, representação e sentido. In: BRANDÃO, H. H. N. Subjetividade, argumentação, polifonia: a propaganda da Petrobrás. São Paulo: Fundação Editora da UNESP, 1998. p. 33-45.

CONEIN, Bernard; COURTINE, Jean-Jacque.; GADET, Françoise; MARADIN, Jean-Marie.; PÊCHEUX, Michel. Materialidades Discursivas. Tradução de Eni Orlandi et al. Campinas: Ed Unicamp, 2016.

FREUD, Sigmund. Os chistes e sua relação com o inconsciente. Tradução sob a direção de Jayme Salomão. Edição Standard Brasileira das Obras Psicológicas Completas de Sigmund Freud. Vol. VIII. Rio de Janeiro: Imago Editora, 1996. 247 p.

ORLANDI, Eni. Análise de Discurso: Michel Pêcheux. Campinas: Pontes, 2011.

PAIXÃO, Fernando. Poema em prosa: problemática (in)definição. Revista Brasileira, Rio de Janeiro, n. 75 (Fase VIII, Ano II), p. 151, 2013.

PÊCHEUX, M.; FUCHS, C. A propósito da análise automática do discurso: atualização e perspectivas. In: GADET, Françoise. HAK, Tony (Org.). Por uma análise automática do discurso. Campinas, Ed. da UNICAMP, 1990. p. 163-252. 
PÊCHEUX, Michel. Semântica e discurso. Campinas, Editora da Unicamp, 1975.

QUEIRÓS, Bartolomeu Campos. Ler, escrever e fazer conta de cabeça. 2. ed. Belo Horizonte: Miguilin, 1997.

SAUSSURE, F. Curso de linguística geral. 6. ed. São Paulo: Cultrix, 1974.

TORGA, V. L. M. O movimento de sentido da alusão: uma estratégia textual da leitura de Ler e escrever e fazer conta de cabeça de Bartolomeu Campos Queiroz. 2001. 98 f. Dissertação (Mestrado em Linguística Aplicada) - Faculdade de Letras da UFMG, Belo Horizonte, 2001.

TORGA, V. L. M. O risco do bordado de Autran Dourado - A alusão nos gêneros textuais: o romance e a tese. 2005. 228 f. Tese (Doutorado em Estudos Linguísticos) - Faculdade de Letras da UFMG, Belo Horizonte, 2005.

\section{Para citar este artigo}

BATISTA, Yuri Andrei; TORGA Vânia Lúcia Menezes. Paráfrase discursiva e o jogo alusivo na escrita (auto) biográfica de Bartolomeu Campos de Queirós. Miguilim - Revista Eletrônica do Netlli, Crato, v. 7, n. 2, p. 288-303, maio-ago. 2018.

\section{Os autores}

Yuri Andrei Batista possui graduação em Letras pela Universidade Estadual de Santa Cruz (UESC) e, atualmente, é aluno de mestrado do Programa de Pósgraduação em Letras: Linguagens e representações (PPGLLR/UESC). Atua nas seguintes áreas: teoria dialógica do discurso, espaço biográfico, estudos de tradução, ensino de línguas estrangeiras, ludoletramento e análise comparativa de discursos.

Vânia Lúcia Menezes Torga possui graduação em Letras, Mestrado em Linguística Aplicada e Doutorado em Linguística pela Faculdade de Letras da Universidade Federal de Minas Gerais. Professora aposentada pela Universidade Estadual de Santa Cruz, é professora colaboradora do Mestrado em Letras: Linguagens e Representações, da mesma universidade. Tem experiência na área de Linguística, com ênfase em Teoria e Análise Linguística, atuando, principalmente, nos seguintes temas: alusão, gêneros discursivos: narrativas literárias autobiográficas, espaço biográfico, análise comparativa dos discursos literários autobiográficos hispano-brasileiros: Bartolomeu Campos Queirós e Carmen Martin Gaite.

\section{Apoio e financiamento: CAPES.}

